Mary was born and raised on a farm at Indian Head, and in turn raised her own family in that rural community. On the Skinner farm in the beautiful Qu'Appelle Valley, there has been a long family tradition of interest in plants and animals and in protecting them. For years the "Skinner Flats" were a sanctuary for wildlife, and these lands have now been acquired by the Department of Tourism and Renewable Resources for a wildlife area.

Mary Skinner's intimate acquaintance with the world around her has made it possible for her to give help and encouragement to others. Young people have sought her out, and have been stimulated by her knowledge and enthusiasm. Under her leadership, a group of interested people at Indian Head organized a summer meeting there in 1971 for the provincial natural history society, and then decided to organize informally as the Indian Head Natural History Society. From 1971 to 1975 Mary Skinner was the Society's president. In that role, she continued to serve on the Board of SNHS, on which she had previously been a director.

Mary Skinner's dedication to the protection of our natural environment is also seen in her public activities in connection with the Qu'Appelle Valley. A member for some years of the Qu'Appelle Valley Development Association, she is now the SNHS representative on the Public Advisory Board to the Qu'Appelle Implementation Board. Although delightfully unassuming in her personal manner, Mary Skinner has for many years been making a strong and convincing contribution to conservation in Saskatchewan. - Margaret Belcher.

\title{
3n 罗parg Ang
}

Notes trom the Oct.-Dec., 1946 , Blue Jay - 10 mimeographed pages: Membership in the Yorkton Natural History Society was 50 cents: this included a subscription to its publication, The Blue Jay ... Walter Mathews of Nipawin discovered an Eastern Kingbird nest on a narrow ledge above the open door of his toolshed. It was in a nest built by robins about a week before ... Evelyn Binnie of Tullis wrote that Lark Buntings "usually nest in the hayfields, but once we found a nest on the railroad tracks, underneath the rails between the ties. The female hatched and raised her brood there, too, but then we only had two trains a week". . . Steve Mann of Skull Creek found a Marsh Hawk nest with three young and one egg 20 feet above the ground in an almond willow. The nest had been used by Swainson's Hawks for the previous 3 years ... Pete Robinson of Nipawin snared and released an immature Bittern that had landed in the top of a jack pine... Mrs. E. Olsgard of Hazlet wrote that there were large numbers of Black Widow Spiders in her area ... H. S. Swallow reported a brief aerial fight between a Great Horned Owl and a Snowy Owl ... There were notes on bat migrations and bird reports by L. T. McKim of Melfort, F. G. Bard and L. T. Carmichael of Regina ... Some band recoveries were also listed: two Black Ducks banded by Stuart Houston at Yorkton were shot the same fall in Ontario and Illinois. He also had Wigeon recoveries from the Dominican Republic and Cuba, a Bufflehead from Mexico and a Pintail from Alaska. In October Maurice Street trapped a White-throated Sparrow that had been banded the previous May in Indiana. 